\title{
An IGF-I gene polymorphism modifies the risk of developing persistent microalbuminuria in type 1 diabetes
}

\author{
Peter Hovind $^{1,4}$, Steven Lamberts ${ }^{2}$, Wim Hop ${ }^{3}$, Jaap Deinum ${ }^{2}$, Lise Tarnow ${ }^{1}$, Hans-Henrik Parving ${ }^{1}$ \\ and Joop A M J L Janssen ${ }^{2}$ \\ ${ }^{1}$ Steno Diabetes Center, Gentofte, Denmark, Departments of ${ }^{2}$ Internal Medicine and ${ }^{3}$ Epidemiology and Biostatistics, Erasmus MC, Room D-436, \\ s-Gravendijkwal, 2303015 CE Rotterdam, The Netherlands and ${ }^{4}$ Department of Clinical Physiology and Nuclear Medicine, Rigshospitalet, University of \\ Copenhagen, Copenhagen, Denmark \\ (Correspondence should be addressed to J A M J L Janssen; Email: j.a.m.j.l.janssen@erasmusmc.nl)
}

\begin{abstract}
Objective: Derangements of the GH-IGF-I axis have been associated with microalbuminuria (MA) in type 1 diabetes. The aim of this study was to investigate whether an IGF-I gene promoter polymorphism influenced the development of persistent MA in type 1 diabetes.

Design: A prospective follow-up study of a cohort of 277 patients with newly diagnosed type 1 diabetes consecutively enrolled between September 1979 and August 1984.

Methods: Urinary albumin excretion rate over $24 \mathrm{~h}$ was measured in each patient at least once a year. Persistent MA was defined as a urinary albumin excretion rate between 30 and $300 \mathrm{mg} / 24 \mathrm{~h}$.

Results: During a median follow-up of 18.0 years (range 1.0-21.5), 79 of 277 patients developed persistent MA. IGF-I gene genotype was available for 216 subjects; in $73 \%$ of the subjects, the wildtype genotype of this IGF-I gene polymorphism was present, while $27 \%$ had the variant type. At baseline, there were no differences in IGF-I levels and $\mathrm{HbA}_{1 \mathrm{c}}$ values between subjects with the wild type and subjects with variant type. By Kaplan-Meier analysis, subjects with the variant type of this polymorphism had during follow-up a higher risk of development of MA compared subjects with the wild type $(P=0.03)$.

Conclusions: Subjects with the variant type of an IGF-I gene polymorphism had a significantly increased risk of developing MA. This risk was not mediated through changes in circulating IGF-I levels. Our study suggests that in type 1 diabetes, this IGF-I gene polymorphism is a risk factor of MA.
\end{abstract}

European Journal of Endocrinology 156 83-90

\section{Introduction}

Insulin-like growth factor-I (IGF-I) bioactivity is regulated by genetic and non-genetic factors like growth hormone, nutrition and insulin. The rate of development of microalbuminuria (MA), an important early marker of diabetic nephropathy, has been related not only to factors such as age at diagnosis, HbAlc, sex and blood pressure, but also with the activity of the growth hormone-insulin-like growth factor-I (GH-IGF-I) axis $(1,2)$. Poor glycaemic control in type 1 diabetes, the most important factor for diabetic complications, is associated with elevated GH secretion and serum IGF binding protein (IGFBP)-1 levels, as well as reduced serum IGF-I levels $(3,4)$. In addition, derangements of the GH-IGF-I axis have been associated with hyperfiltration and $\mathrm{MA}$ in type 1 diabetes (5-7). The mechanism behind this imbalance in the GH-IGF-I axis in type 1 diabetes has been suggested to be due to relatively low portal insulin levels resulting from s.c. administration of insulin $(8,9)$. Complete correction of the GH-IGF-I axis only seems possible with portal administration of insulin (10). However, this is not a clinically available option at the moment.

Recent observations in an animal model of glomerulosclerosis showed that, in contrast to previous thoughts, not elevated but lowered circulating IGF-I levels may be involved in the induction of (diabetic) glomerulosclerosis (11). Doublier et al. provided the first evidence that the lesions of glomerulosclerosis are related to a reduction in circulating IGF-I and an increase in IGFBP-1 levels (11). The same clinical picture (reduced circulating IGF-I and increased IGFBP-1 levels) has been found in human diabetics that develop microalbuminuria $(12,13)$.

A highly polymorphic cytosine-adenine (CA) dinucleotide repeat $1 \mathrm{~kb}$ upstream from the start site of the IGF-I promoter has been identified. Studies of other genes have suggested that polymorphic CA repeats in the promoter region of gene affect transcription activity of a gene (14). Thus, this CA repeat polymorphism in the IGF-I gene has the potential to influence the IGF-I expression directly at the tissue level and, may therefore, serve as a better indicator of life-long IGF-I exposure 
than circulating IGF-I (15). Although others found no relationship or even reported lower circulating IGF-I levels in subjects, homozygous for the wild-type allele of this IGF-I gene polymorphism compared with those that were non-carriers or heterozygous for the wild-type allele (16-19), we recently observed in a populationbased sample, like Missmer et al. (20), that subjects homozygous for the wild-type alleles of this IGF-I gene polymorphism had higher serum IGF-I levels than subjects that were non-carriers of the wild-type alleles (21). Possible explanations for these discrepant observations might be due to chance, unknown confounders, variations in patterns of linkage disequilibrium between populations, different study designs and methods used to measure IGF-I across studies (22).

Nevertheless, when future studies would confirm our findings showing that there is indeed a relationship between IGF-I levels and this IGF-I gene polymorphism, this will open the opportunity to characterize on a genetic basis individuals with life-long exposure to either relatively low- or high-IGF-I activity.

The aim of the present study was to investigate whether this IGF-I gene promoter polymorphism is related to the development of persistent MA in type 1 diabetes.

\section{Subjects and methods}

The study population for the present study comprised all patients newly diagnosed with type 1 diabetes and consecutively admitted to the Steno Diabetes Centre between 1 September 1979 and 31 August 1984. As all newly diagnosed patients with type 1 diabetes were enrolled, the study population was a so-called inception cohort. Their health characteristics have been previously published (23). Briefly, the starting cohort included 286 patients (see Fig. 1). Nine patients were excluded; seven had serious mental illness and two had $\mathrm{MA}$ at the onset of diabetes, so that 277 subjects were eligible for the analyses at baseline. During the followup, five patients were excluded due to other serious or psychomedical conditions. Nineteen subjects emigrated or were lost during follow-up. Thirty-one subjects died during follow-up, so that finally 222 patients could be followed from diabetes onset until December 2000. The patients attended the outpatient clinic every three or four months as part of routine follow-up. They were treated by diabetologists and nurses according to previously described guidelines (24). None of these subjects were participating in other studies or treated by experimental drugs.

The genotypes were determined in 2004. The DNA material was collected in the period 1996-1998. From 222 subjects, permission to genotype was available and IGF-I genotyping was successful in 216 out of 222 subjects (for details see below). The local ethics committee (Copenhagen, Denmark) approved the experimental design, and all the patients gave written informed consent to participate in this study.

\section{Measurements}

Arterial blood pressure was measured at least once a year with a standard mercury sphygmomanometer and an appropriate cuff size. The measurements were performed with the patient in the sitting position after 10 min rest. From 1 January 1980, haemoglobin $A_{1 c}$ was measured at each visit. The method used for measuring $\mathrm{HbA}_{1 \mathrm{c}}$ from venous blood samples has changed over the years; the predominate method has been HPLC ion-exchange using a normal range of 4.1$6.4 \%$ (23). Basal serum C peptide levels were measured by RIA after an overnight fast (normal value, 0.200$0.700 \mathrm{nmol} / \mathrm{l})(25)$.

Urinary albumin excretion rate over $24 \mathrm{~h}$ (UAER) was measured in each patient at least once a year (24). UAER was quantitated using automated immunotopical nephelometric analysis (26); from 1984 to 1990, using RIA (sensitivity $0.5 \mathrm{mg} / \mathrm{l}$, coefficient of variation (CV) 9\%) (27); and from 1990 on, using enzyme immunoassay (sensitivity $1.1 \mathrm{mg} / \mathrm{l}, \mathrm{CV} 8 \%$ ) (28). A very close correlation between radial immunodiffusion and RIA $(r=0.98)$ and RIA and enzyme immunoassay $(r=0.99)$ was documented before changing the methods (29). From 1997, the DAKO Turbidimetric method (DAKO, Glostrop, Denmark) was used to measure UAER. This method is closely correlated with enzyme immunoassay $(r=0.99)$ and has a CV of 5\%. Persistent micro- and macroalbuminuria were defined as a UAER of 30$300 \mathrm{mg} / 24 \mathrm{~h}$ and more than $300 \mathrm{mg} / 24 \mathrm{~h}$ in at least two of three consecutive samples respectively with at least a 30\% increase above baseline (30).

\section{Measurement of serum total and free IGF-I}

Blood samples were taken by venipuncture and allowed to coagulate for $30 \mathrm{~min}$. Serum was then separated by centrifugation and stored at $-20{ }^{\circ} \mathrm{C}$ until measurement of IGF-I. For the present study, serum from 233 subjects was available to measure IGF-I parameters. IGF-I levels were measured at $1.2 \pm 0.8$ years (mean \pm s.D.) after the onset of diabetes. There was no difference in storage time of the blood samples between the two genotypes.

Total and free IGF-I were assayed in the fasting state with commercially available IRMAs (Diagnostic Systems Laboratories (DSL), Webster, Texas, USA) in 2003. The free IGF-I assay of DSL measures a combination of the true free and the fraction of IGF-I, which can be readily dissociated from the IGFBPs under the specific assay conditions. Technicians performing assays were blinded to the albuminuria status of subjects, and quality control samples were included within assay runs. Interassay coefficients of variation for total IGF-I and free IGF-I were 8.2 and $10.3 \%$ respectively. Intraassay coefficients of variation for total 


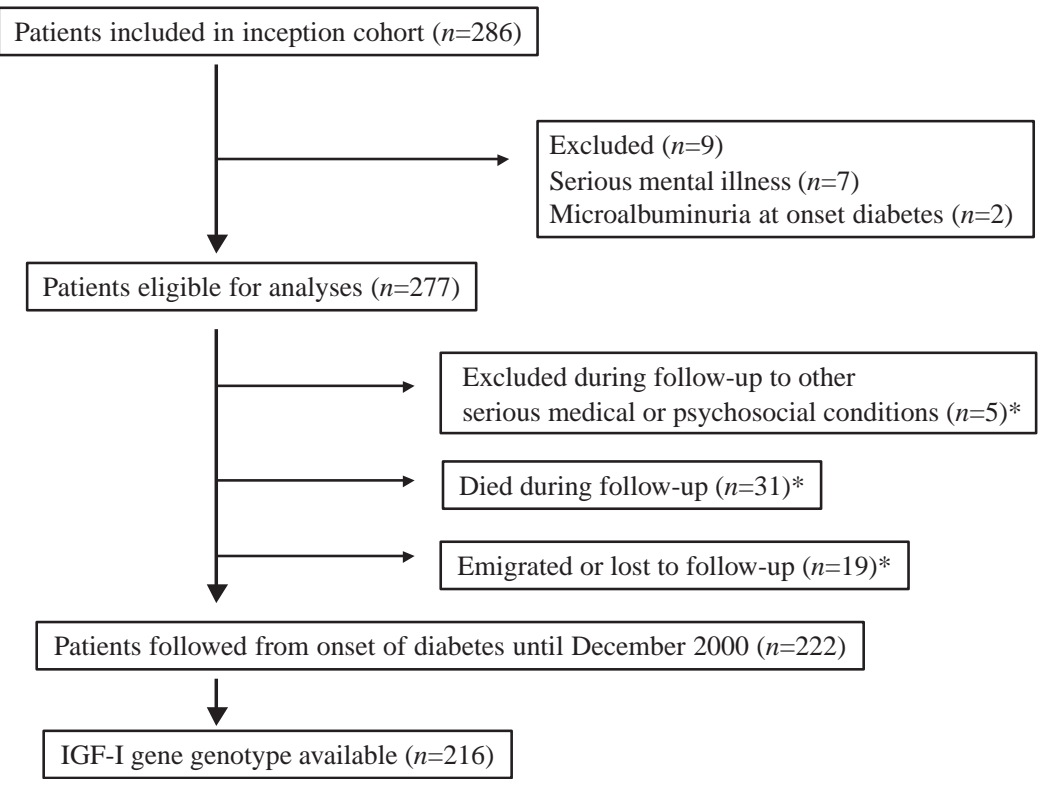

Figure 1 Study design. *Excluded during follow up (patients censored from time of event in case of emigration or incomplete follow-up).
IGF-I and free IGF-I were 3.4 and $10.7 \%$ respectively. With the help of age- and gender-specific normative data, we calculated for each individual the Z-scores for total IGF-I and free IGF-I respectively. For free IGF-I, normative data used in the normal population have been published (31), while for total IGF-I, we used reference values provided by Diagnostic Systems Laboratories utilizing data from 1700 individuals (www.DSLabs.com). The individual Z-score was calculated using the following formula: $Z$-score $=(x$-average $x /$ s.D.) where $x$ is the actual IGF-I level, average $x$ is the mean IGF-I level at that age and for that sex, and s.D. is standard deviation for the mean at that age).

\section{Determination of IGF-I genotypes}

PCR was performed using oligonucleotide primers designed to amplify the polymorphic cytosine-adenine repeat $1 \mathrm{~kb}$ upstream of the promoter of the IGF-I gene as described previously. The reaction was carried out in a final volume of $7.5 \mu \mathrm{l}$ containing at least $5 \mathrm{ng}$ of genomic DNA, $0.5 \mathrm{nmol} / \mathrm{l}$ forward primer $\left(5^{\prime}\right.$-ACCACTCTGGGAGAAGGGTA-3 $\left.{ }^{\prime}\right), 0.5 \mathrm{nmol} / \mathrm{l}$ reverse primer $\left(5^{\prime}\right.$ GCTAGCCAGCTGGTGTTATT-3'), $0.25 \mathrm{mmol} / \mathrm{l}^{\prime}$ ' $^{\prime} \mathrm{dNTP}$, $2.2 \mathrm{mmol} / \mathrm{l} \mathrm{MgCl}_{2}, 0.01 \% \mathrm{~W} 1$ (Gibco BRL) and 0.4 Taq DNA polymerase (Gibco BRL).

PCR is performed in 384 well plates $\left(94^{\circ} \mathrm{C} 10 \mathrm{~min}\right.$; $35 \mathrm{PCR}$ cycles of $30 \mathrm{~s}$ at $94^{\circ} \mathrm{C}, 30 \mathrm{~s}$ on $55^{\circ} \mathrm{C}$ and $30 \mathrm{~s}$ on $72{ }^{\circ} \mathrm{C} ; 72{ }^{\circ} \mathrm{C} 10 \mathrm{~min} ; 4^{\circ} \mathrm{C}$ hold). Forward primers are labelled with FAM, HEX or NED (Applera Europe BV, Nieuwerkerk a/d, Ijssel, The Netherlands) to determine the size of PCR products by auto sequencer (ABI 377, 6.25\% long-ranger gel, filter set D, peak height between 100 and 2000, each lane containing three samples; Applied Biosystems, Nieuwerkerk a/d,
Ijssel, The Netherlands). The size of the PCR products is determined in comparison with internal ROX 500-size standard. The human IGF-I gene contains a polymorphic $\mathrm{CA}$ repeat $1 \mathrm{~kb}$ upstream of the promoter region (32). IGF-I genotypes were determined as described previously (32). Overall, the repeat lengths vary from a minimum of 10 repeats to a maximum of 23 repeats with two alleles, the 19 and the 20 repeat alleles predominating in Caucasians (70 and 17\% respectively (18). The allelic distribution frequency of the CA-repeat IGF-I promoter polymorphism was almost comparable as we previously observed within the Rotterdam Study (Table 1). In addition, since the $192 \mathrm{bp}$ and the $194 \mathrm{bp}$ alleles had by far the highest frequencies, we considered these two alleles as the wildtype alleles from which all other alleles originated. Therefore, we decided to pool the other eight alleles in the further analysis.

In the Rotterdam study, we primarily examined the functional role of the various lengths of the alleles of the IGF-I promoter polymorphism and did the following observations (32): mean IGF-I levels and body height for homozygous carriers of the 192 bp allele and homozygous carriers of the $194 \mathrm{bp}$ allele of this IGF-I gene promoter polymorphism were almost equal and significantly higher than the values measured in subjects homozygous for alleles smaller than $192 \mathrm{bp}$ and longer than $194 \mathrm{bp}$ respectively. Both observations suggest that homozygous carriers of the $192 \mathrm{bp}$ allele and homozygous carriers of the $194 \mathrm{bp}$ allele of this IGF-I gene promoter polymorphism are life-long exposed to relatively higher IGF-I levels throughout the body than subjects homozygous for alleles smaller than $192 \mathrm{bp}$ and subjects with alleles longer than $194 \mathrm{bp}$ of this IGF-I gene polymorphism (for more details see 32 ). 
Table 1 Allelic distribution of the insulin-like growth factor-I promoter polymorphism in patients with newly diagnosed type 1 diabetes and in the Rotterdam study.

\begin{tabular}{lccc}
\hline $\begin{array}{l}\text { Allele } \\
\text { (\# base pairs) }\end{array}$ & CA $(n)$ & $\begin{array}{c}\text { Type 1 diabetes } \\
(n=216 ; \%)\end{array}$ & $\begin{array}{c}\text { Rotterdam } \\
\text { study } \\
(n=9278 ; \%)\end{array}$ \\
\hline $188 \mathrm{bp}^{\mathrm{a}}$ & 17 & 1.6 & 1.8 \\
$190 \mathrm{bp}^{\mathrm{a}}$ & 18 & 4.2 & 4.5 \\
$192 \mathrm{bp}^{\mathrm{b}}$ & 19 & 65.9 & 65.5 \\
$194 \mathrm{bp}^{\mathrm{b}}$ & 20 & 19.7 & 19.3 \\
$196 \mathrm{bp}^{\mathrm{a}}$ & 21 & 6.0 & 6.9 \\
$198 \mathrm{bp}^{\mathrm{a}}$ & 22 & 1.6 & 1.5 \\
Other rare $^{\text {alleles }}$ & - & 1.5 & 0.5 \\
\hline
\end{tabular}

$\mathrm{CA}$, cytosine-adenine; percentages are based on allele frequencies of the pooled populations. See 'Subjects and methods' for further details.

avariant type allele.

bWild-type allele.

Based on carriership of the 192 and $194 \mathrm{bp}$ alleles, we distinguished two different IGF-I genotypes: as wild-type genotype we considered subjects homozygous for the $192 \mathrm{bp}$ or for the $194 \mathrm{bp}$ allele of the IGF-I gene, and subjects heterozygous for these two alleles (participants with this genotype are further denoted as subjects with the wild type). Participants with all other combinations of alleles of the IGF-I gene (i.e. those with combinations of alleles more than $192 \mathrm{bp}$ and/or alleles less than $194 \mathrm{bp}$ ) were considered as carriers of the variant genotype (further denoted as the variant type).

\section{Statistical analysis}

Baseline data were from the first assessment, six months after the onset of type 1 diabetes, after initial glycaemic stabilization. Results are presented as means with S.D.. Urinary albumin excretion and circulating total and IGF-I and C-peptide levels did not meet the criteria for normality and were logarithmically transformed before the analysis in order to obtain approximately normal distribution. Therefore, results of these parameters are presented as medians or geometric means. Groups were compared with the Mann-Whitney test or the KruskalWallis test when appropriate.

To get a better impression of total exposure in the first 5 years of follow-up, measurements for systolic blood pressure, diastolic blood pressure, HbA1c, serum cholesterol, MA and insulin doses in the first 5 years of follow-up were averaged to compute per patient the summary means for these variables.

Analysis of cumulative incidence of MA was conducted using the Kaplan-Meier method and cumulative incidence curves of MA were compared with the logrank test. Cox regression analysis was used to adjust for differences in characteristics between the two groups that might have affected cumulative incidence of MA (age at onset of diabetes, sex, C-peptide levels at baseline, averaged $\mathrm{HbA} 1 \mathrm{c}$ in the first 5 years of follow-up, systolic blood pressure first 5 years of follow-up, diastolic blood pressure first 5 years of follow-up and insulin dose first 5 years of follow-up). A forward-stepwise method was used to select variables significantly associated with outcome.

A two-sided $P$-value of 0.05 or less was considered as significant. All the analyses were performed using the SPSS for Windows software package, version 10.0.5 (SPSS Inc., Chigcago, IL, USA).

\section{Results}

Table 2 shows the characteristics of the study population at baseline. The large majority of the study population showed reduced serum levels of IGF-I (i.e. Zscores $<0$ ) at baseline.

During a median follow-up of 18.0 years (range 1.0-21.5 years) 79 of 277 patients developed persistent MA (Table 2). Among these, 27 progressed to persistent macroalbuminuria. More men than women developed persistent MA (MA+: 55 males/ 24 females vs MA-: 108 males/90 females; $P=0.02$ ). When grouped according to the presence/absence of MA, blood pressure was significantly higher in the first 5 year of diabetes, and blood glucose control - as assessed by $\mathrm{HbA} 1 \mathrm{c}$ - was significantly worser in those who developed persistent MA (Table 3). At baseline, there were no differences in age, plasma (free and total) IGF-I (neither for the measured levels nor for the $\mathrm{Z}$ scores) and C-peptide between subjects who progressed to persistent MA and who did not (Table 2). In $73 \%$ percent of the patients, the wild type of this IGF-I gene promoter polymorphism was present, while $27 \%$ had the variant type.

Table 2 Baseline clinical characteristics of the study population ( $n=277 ; 163$ males and 114 females).

\begin{tabular}{|c|c|c|}
\hline & Mean & S.D. \\
\hline Age onset DM (years) & 26.9 & 13.8 \\
\hline Syst BP $(\mathrm{mmHg})$ & 123.4 & 16.8 \\
\hline Diast BP $(\mathrm{mmHg})$ & 77.4 & 10.8 \\
\hline $\mathrm{HbA1c}(\%)$ & 9.83 & 2.12 \\
\hline $\begin{array}{l}\text { Serum cholesterol } \\
(\mathrm{mmol} / \mathrm{l})\end{array}$ & 5.49 & 1.48 \\
\hline \multirow[t]{2}{*}{ Serum creatinine $(\mu \mathrm{mol} / \mathrm{l})$} & 79.0 & 15.6 \\
\hline & Median & P25-P75 \\
\hline $\begin{array}{l}\text { Serum total IGF-I } \\
(\mathrm{nmol} / \mathrm{l})\end{array}$ & 15.5 & $10.2-23.5$ \\
\hline Z-score & -1.35 & $(-1.88)-(-0.84)$ \\
\hline $\begin{array}{l}\text { Serum free IGF-I } \\
(\mathrm{pmol} / \mathrm{l})\end{array}$ & 64 & $33-130$ \\
\hline Z-score & -5.35 & $(-6.71)-(-1.62)$ \\
\hline $\begin{array}{l}\text { Plasma C-peptide } \\
\text { (nmol/l) }\end{array}$ & 0.170 & $0.100-0.240$ \\
\hline
\end{tabular}

DM, diabetes mellitus; Syst BP, systolic blood pressure; Diast BP, diastolic blood pressure; IGF-I, insulin-like growth factor-I. 
Table 3 Clinical characteristics in the first 5 years after the onset of diabetes comparing 198 subjects who developed no microalbuminuria $(\mathrm{MA}-)$, with 79 subjects who developed microalbuminuria $(\mathrm{MA}+)$ at follow-up.

\begin{tabular}{|c|c|c|c|c|c|}
\hline & \multicolumn{2}{|c|}{ MA - } & \multicolumn{2}{|r|}{ MA + } & \multirow[b]{2}{*}{$P$ value } \\
\hline & Mean & S.D. & Mean & S.D. & \\
\hline $\begin{array}{l}\text { Syst BP }(\mathrm{mmHg}) 0-5 \\
\text { years }^{\mathrm{b}}\end{array}$ & 121.3 & 13.6 & 127.6 & 17.3 & 0.004 \\
\hline $\begin{array}{l}\text { Diast BP }(\mathrm{mmHg}) 0-5 \\
\text { years }^{\mathrm{b}}\end{array}$ & 75.9 & 8.5 & 79.3 & 8.6 & 0.001 \\
\hline HbA1c (\%) 0-5 years ${ }^{b}$ & 8.22 & 1.22 & 8.94 & 1.11 & $<0.001$ \\
\hline $\begin{array}{l}\text { Serum cholesterol } \\
\quad(\mathrm{mmol} / \mathrm{l}) 0-5 \text { years }^{\mathrm{b}}\end{array}$ & 5.58 & 1.39 & 5.82 & 1.53 & 0.26 \\
\hline $\begin{array}{l}\text { Serum creatinine } \\
(\mu \mathrm{mol} / \mathrm{l}) 0-5 \text { years }^{\mathrm{b}}\end{array}$ & 80.7 & 14.9 & 78.2 & 14.7 & 0.22 \\
\hline $\begin{array}{l}\text { Insulin dose U/day 0-5 } \\
\text { years }^{\text {b }}\end{array}$ & 31 & 9 & 32 & 10 & 0.37 \\
\hline \multirow[t]{2}{*}{ Age onset DM (years) } & 26.9 & 12.7 & 27.0 & 16.4 & 0.40 \\
\hline & Median & P25-P75 & Median & P25-P75 & $P$ value $^{a}$ \\
\hline \multirow{2}{*}{$\begin{array}{l}\text { Urinay albumin } \\
\quad(\mathrm{mg} / 24 \mathrm{~h}) 0-5 \text { years }^{\mathrm{c}}\end{array}$} & 10 & $7-16$ & 17 & $8-37$ & $<0.001$ \\
\hline & Median & P25-P75 & Median & P25-P75 & $P$ value ${ }^{a}$ \\
\hline $\begin{array}{l}\text { Baseline serum total } \\
\text { IGF-I (nmol/l) }\end{array}$ & 15.3 & $10.1-22.8$ & 17.1 & $10.2-25.5$ & 0.58 \\
\hline$Z$-score & -1.39 & -1.86 to -0.87 & -1.23 & -2.09 to -0.66 & 0.22 \\
\hline $\begin{array}{l}\text { Baseline serum free } \\
\text { IGF-I (pmol//) }\end{array}$ & 65 & $34-131$ & 56 & $33-126$ & 0.44 \\
\hline$Z$-score & -5.04 & -6.64 to -1.62 & -5.63 & -6.84 to -1.62 & 0.27 \\
\hline $\begin{array}{l}\text { Baseline plasma } \\
\text { C-peptide (nmol/l) }\end{array}$ & 0.16 & $0.10-0.24$ & 0.18 & $0.10-0.24$ & 0.70 \\
\hline
\end{tabular}

The duration of diabetes of the successfully genotyped 216 subjects followed from 1979-1984 to 2000 was almost equal in the two groups: wild type: $18.4( \pm 1.6)$ (mean \pm s.D.) years vs variant type: $18.7( \pm 1.4)$ years. At baseline and during follow-up, there were no differences in IGF-I levels between the subjects with the wild type and variant type of this IGF-I gene polymorphism (Table 4). In both variant type as well as subjects with the wild type, more than $90 \%$ of the Zscores for total IGF-I and free IGF-I were already less than 0 at baseline (data not shown).

The first 5 years subjects with the variant type had significantly higher blood pressure and urinary albumin excretion than subjects with the wild type (Table 5), while plasma C-peptide levels and daily insulin dose were not significantly different from subjects with the wild type (Table 5).

The cumulative incidence of persistent MA was significantly higher in subjects with the variant type than in subjects with the wild type $(P=0.03)$ (Fig. 2; cumulative incidence of persistent MA after 18 years follow-up: wild type $24 \%$ and variant type: $42 \%$ ). Results of the forward-stepwise method used in the Cox model to adjust for differences in characteristics between the two groups, included finally IGF-I genotype $(P=0.03), \mathrm{HbAl} \mathrm{c}$ in the first 5 years $(P<$ $0.001)$ and gender $(P=0.01)$ as factors that were found to affect the incidence of MA. In this model, the

Table 4 Geometric means for free and total insulin-like growth factor-I (IGF-I) comparing subjects with the wild type and the variant type at baseline.

\begin{tabular}{|c|c|c|c|c|c|}
\hline & \multicolumn{2}{|c|}{ Wild type } & \multicolumn{2}{|c|}{ Variant type } & \multirow[b]{2}{*}{$P$ value $^{\mathrm{a}}$} \\
\hline & Geometric mean & $95 \% \mathrm{Cl}$ & Geometric mean & $95 \% \mathrm{Cl}$ & \\
\hline Free IGF-I (pmol/l) & 76 & $65-90$ & 69 & 52-91 & 0.52 \\
\hline Total IGF-I (nmol/l) & 15.6 & $14.3-17.0$ & 17.7 & $15.2-20.7$ & 0.15 \\
\hline
\end{tabular}

$\mathrm{Cl}$, confidence interval.

a Blood drawn at baseline $1.2( \pm 0.8)$ years (mean $( \pm$ s.D. $)$ ) after the onset of diabetes. 
Table 5 Clinical characteristics in the first five years after the onset of diabetes mellitus (DM) comparing 158 subjects (87M/71F) with the wild type and 58 subjects $(37 \mathrm{M} / 21 \mathrm{~F})$ with the variant type of this IGF-I gene promoter polymorphism.

\begin{tabular}{|c|c|c|c|c|c|}
\hline & \multicolumn{2}{|c|}{ Wild type } & \multicolumn{2}{|c|}{ Variant type } & \multirow[b]{2}{*}{$P$ value } \\
\hline & Mean & S.D. & Mean & S.D. & \\
\hline Age onset DM (years) & 25.3 & 12.5 & 28.2 & 14.1 & 0.16 \\
\hline Syst BP $(\mathrm{mm} \mathrm{Hg}) 0-5$ years $^{\mathrm{a}}$ & 121.0 & 12.5 & 125.9 & 16.2 & 0.07 \\
\hline $\begin{array}{l}\text { Diast } \mathrm{BP}(\mathrm{mm} \mathrm{Hg}) 0-5 \\
\text { years }^{\mathrm{a}}\end{array}$ & 75.3 & 7.6 & 79.0 & 10.5 & 0.05 \\
\hline $\mathrm{HbA1c}(\%) 0-5$ years $^{\mathrm{a}}$ & 8.29 & 1.15 & 8.32 & 1.15 & 0.75 \\
\hline $\begin{array}{l}\text { Serum cholesterol }(\mathrm{mmol} / \mathrm{l}) \\
0-5 \text { years }^{\mathrm{a}}\end{array}$ & 5.50 & 1.31 & 5.47 & 1.35 & 0.88 \\
\hline $\begin{array}{l}\text { Serum creatinine }(\mu \mathrm{mol} / \mathrm{l}) \\
0-5 \text { years }^{\mathrm{a}}\end{array}$ & 79.4 & 13.6 & 81.0 & 13.6 & 0.55 \\
\hline \multirow{2}{*}{$\begin{array}{l}\text { Insulin dose U/day 0-5 } \\
\text { years }^{\mathrm{a}}\end{array}$} & 31 & 9 & 30 & 9 & 0.56 \\
\hline & Median & P25-P75 & Median & P25-P75 & $P$ value \\
\hline \multirow{2}{*}{$\begin{array}{l}\text { Urinay albumin } \\
\text { secretion } \\
\text { (mg/24 h) 0-5 years }{ }^{\text {b }}\end{array}$} & 11 & $7-20$ & 14 & $9-28$ & 0.02 \\
\hline & Median & P25-P75 & Median & P25-P75 & $P$ value \\
\hline $\begin{array}{l}\text { Baseline C-peptide } \\
(\mathrm{nmol} / \mathrm{l})\end{array}$ & 0.16 & $0.10-0.24$ & 0.18 & $0.10-0.25$ & 0.44 \\
\hline
\end{tabular}

Syst BP, systolic blood pressure; Diast BP, diastolic blood pressure.

Median baseline C-peptide levels are also shown for both groups. P25-P75, percentile range 25-75.

${ }^{a}$ Mean values observed during the first 5 years of diabetes.

${ }^{b}$ Median values observed during the first 5 years of diabetes.

incidence of microalbuminuria in subjects with the variant type was significantly higher than in subjects with the wild type.

\section{Discussion}

The most important finding of the present prospective study in a cohort of newly diagnosed type 1 diabetic patients is that - despite a comparable metabolic control in the first 5 years of diabetes - subjects with the variant type of an IGF-I gene promoter polymorphism demonstrated an increased risk to develop persistent MA compared with subjects with the wild type. Since we did not observe a clear relationship between this IGF-I gene promoter polymorphism and circulating IGF-I levels, our findings suggest that this effect on MA is not mediated through changes in circulating IGF-I levels.

In contrast to circulating IGF-I levels, the IGF-I gene variant of an individual is fixed for life and not susceptible to potential confounding factors such as age, insulin deficiency, hyperglycaemia and nutrition state. An explanation is that IGF-I gene variants are simply risk factors and/or markers for phenotypes related to IGF-I expression (33). However, it is unknown at present whether this IGF-I gene promoter polymorphism directly affects expression of IGF-I in the body and is related to paracrine/autocrine IGF-I production in the kidney, pancreas and other organs. This latter aspect could be very important because it is thought that the IGF-I system has important paracrine/autocrine actions. In addition, it has been suggested that circulating and local IGF-I levels are regulated independently (34).

At baseline, after initiation of s.c. insulin treatment and initial glycaemic stabilization but prior to the development of persistent MA, circulating (free and total) IGF-I were reduced and lower than normal in the large majority of our study population. This observation is in agreement with most previous studies, which have demonstrated that individuals with type 1 diabetes have decreased circulating IGF-I levels $(5,13)$. Although s.c. insulin treatment may raise reduced circulating IGF-I levels, Shisko et al. demonstrated that s.c. insulin treatment cannot completely normalize lowered

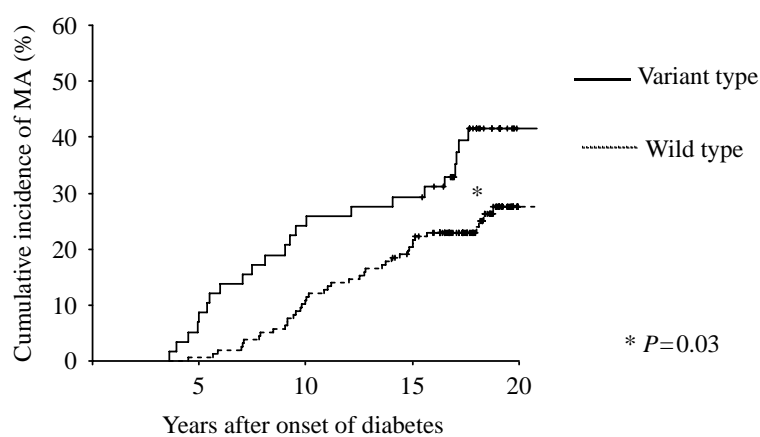

Figure 2 The cumulative incidence of persistent microalbuminuria (MA) in variant carriers and in subjects with the wild type of this IGF-I gene polymorphism. 
circulating IGF-I and increased GH secretion in type 1 diabetes (10). As a consequence, consistently lowered levels of circulating IGF-I have been reported in type 1 diabetics (8). Circulating (total and free) IGF-I levels did not significantly differ between subjects with the variant type and subjects with the wild type. In contrast with the present study, we previously observed in a population-based study that in normal healthy individuals and persons with type 2 diabetes subjects with the variant type of this IGF-I gene polymorphism had significantly lower normal serum total IGF-I levels than subjects with the wild type (32). There are several factors that might explain the lack of a relationship between circulating IGF-I and this IGF-I gene polymorphism in the present study. Firstly, the loss of endogenous insulin production and/or the s.c. administration of insulin may have masked genetically mediated differences in circulating IGF-I levels. The loss of endogenous insulin production and exogenous insulin administration profoundly affect the circulating IGF-I levels in type 1 diabetes (10). S.c. insulin therapy in type 1 diabetes leads inevitable to under-insulinization of the liver, and this may explain why serum IGF-I levels were lowered (10). Secondly, the present study was not population-based and initially not powered or designed to study differences in IGF-I levels between IGF-I gene variants. Thirdly, it remains still possible that this polymorphism is in linkage disequilibrium with another functional polymorphism. In addition, other confounding factors may have obscured a genetically determined difference in circulating IGF-I, like for instance, the degree of metabolic control.

Some technical issues might have influenced our results. IGF-I immunoassays can be compromised in diabetics because of IGFBP interferences and glycation of some IGF-I epitopes (35). Our study could be further criticized because we used blood samples that had been stored for more than 10 years. IGF-I instability theoretically could have affected the IGF-I concentrations measured. However, it has been also reported that there is little evidence of degradation of IGF-I in samples stored for up to 21 years (36).

In general, we observed no differences in $\mathrm{HbA}_{1 \mathrm{c}}$ concentrations between subjects with the wild type and subjects with the variant type during the first 5 years after the development of diabetes, but blood pressure was significantly higher in subjects with the variant type than in subjects with the wild type. There is increasing evidence that IGF-I may affect vascular tone in addition to its well-recognized metabolic and trophic actions (37). IGF-I is also produced locally by endothelial and vascular smooth muscle cells, and this paracrine IGF-I may be more important in regulating regional blood flow than circulating IGF-I (38). Several experimental studies have shown that IGF-I induces vasorelaxation in normotensive rat arteries, while this is abolished by treatment with a nitric oxide inhibitor or removal of the endothelium (39). When this mechanism is also present in humans, our study suggests that subjects with the variant type have less autocrine/paracrine IGF-I mediated vasorelaxation than wild-type carriers.

In conclusion, subjects with the variant type of an IGF-I gene polymorphism had an increased risk of developing persistent MA. Our study suggests that after the development of type 1 diabetes, this IGF-I gene polymorphism is a risk factor for MA. This IGF-I gene polymorphism may modulate the susceptibility and/or progression of MA.

\section{Acknowledgements}

This study was partly supported by a grant of the Dutch Diabetes Foundation. We would like to thank Pascal Arp and Andre Uitterlinden for their help in genotyping. We are grateful to René de Bruin and Piet Uitterlinden for their skilful and dedicated assistance.

\section{References}

1 Flyvbjerg A. Role of growth hormone, insulin-like growth factors (IGFs) and IGF-binding proteins in the renal complications of diabetes. Kidney International Supplement 199760 S12-S19.

2 Schultz CJ, Konopelska-Bahu T, Dalton RN, Carroll TA, Stratton I, Gale EA, Neil A \& Dunger DB. Microalbuminuria prevalence varies with age, sex, and puberty in children with type 1 diabetes followed from diagnosis in a longitudinal study. Oxford Regional Prospective Study Group. Diabetes Care 199922 495-502.

3 Clayton KL, Holly JM, Carlsson LM, Jones J, Cheetham TD, Taylor AM \& Dunger DB. Loss of the normal relationships between growth hormone, growth hormone-binding protein and insulinlike growth factor-I in adolescents with insulin-dependent diabetes mellitus. Clinical Endocrinology 1994 41 517-524.

4 Janssen JA, Jacobs ML, Derkx FH, Weber RF, van der Lely AJ \& Lamberts SW. Free and total insulin-like growth factor I (IGF-I), IGF-binding protein-1 (IGFBP-1), and IGFBP-3 and their relationships to the presence of diabetic retinopathy and glomerular hyperfiltration in insulin-dependent diabetes mellitus. Journal of Clinical Endocrinology and Metabolism 199782 2809-2815.

5 Amin R, Schultz C, Ong K, Frystyk J, Dalton RN, Perry L, Orskov H \& Dunger DB. Low IGF-I and elevated testosterone during puberty in subjects with type 1 diabetes developing microalbuminuria in comparison to normoalbuminuric control subjects: the Oxford Regional Prospective Study. Diabetes Care 200326 1456-1461.

6 Amin R, Williams RM, Frystyk J, Umpleby M, Matthews D, Orskov H, Dalton RN \& Dunger DB. Increasing urine albumin excretion is associated with growth hormone hypersecretion and reduced clearance of insulin in adolescents and young adults with type 1 diabetes: the Oxford Regional Prospective Study. Clinical Endocrinology 200562 137-144.

7 Blankestijn PJ, Derkx FH, Birkenhager JC, Lamberts SW, Mulder P, Verschoor L, Schalekamp MA \& Weber RF. Glomerular hyperfiltration in insulin-dependent diabetes mellitus is correlated with enhanced growth hormone secretion. Journal of Clinical Endocrinology and Metabolism 199377 498-502.

8 Dunger DB, Regan FM \& Acerini CL. Childhood and adolescent diabetes. Endocrine Development 20059 107-120.

9 Moller $\mathrm{N} \&$ Orskov H. Does IGF-I therapy in insulindependent diabetes mellitus limit complications? Lancet 1997 350 1188-1189. 
10 Shishko PI, Dreval AV, Abugova IA, Zajarny IU \& Goncharov VC. Insulin-like growth factors and binding proteins in patients with recent-onset type 1 (insulin-dependent) diabetes mellitus: influence of diabetes control and intraportal insulin infusion. Diabetes Research and Clinical Practice 199425 1-12.

11 Doublier S, Seurin D, Fouqueray B, Verpont MC, Callard P, Striker LJ, Striker GE, Binoux M \& Baud L. Glomerulosclerosis in mice transgenic for human insulin-like growth factor-binding protein-1. Kidney International 200057 2299-2307.

12 Barkai L \& Tombacz A. Alterations in insulin-like growth factor binding protein-1 and sex hormone binding globulin levels in type 1 diabetic adolescents with microalbuminuria. Diabetes Care 2001 24 605-606.

13 Spagnoli A, Chiarelli F, Vorwerk P, Boscherini B \& Rosenfeld RG. Evaluation of the components of insulin-like growth factor (IGF)IGF binding protein (IGFBP) system in adolescents with type 1 diabetes and persistent microalbuminuria: relationship with increased urinary excretion of IGFBP-3 $18 \mathrm{kD}$ N-terminal fragment. Clinical Endocrinology 199951 587-596.

14 Tae HJ, Luo X \& Kim KH. Roles of CCAAT/enhancer-binding protein and its binding site on repression and derepression of acetyl-CoA carboxylase gene. Journal of Biological Chemistry 1994 269 10475-10484.

15 Yu H, Li BD, Smith M, Shi R, Berkel HJ \& Kato I. Polymorphic CA repeats in the IGF-I gene and breast cancer. Breast Cancer Research and Treatment 200170 117-122.

16 Allen NE, Davey GK, Key TJ, Zhang S \& Narod SA. Serum insulinlike growth factor I (IGF-I) concentration in men is not associated with the cytosine-adenosine repeat polymorphism of the IGF-I gene. Cancer Epidemiology Biomarkers and Prevention 200211 319-320.

17 Frayling TM, Hattersley AT, McCarthy A, Holly J, Mitchell SM, Gloyn AL, Owen K, Davies D, Smith GD \& Ben-Shlomo Y. A putative functional polymorphism in the IGF-I gene: association studies with type 2 diabetes, adult height, glucose tolerance, and fetal growth in U.K. populations. Diabetes $2002512313-2316$.

18 Jernstrom H, Deal C, Wilkin F, Chu W, Tao Y, Majeed N, Hudson T, Narod SA \& Pollak M. Genetic and nongenetic factors associated with variation of plasma levels of insulin-like growth factor-I and insulin-like growth factor-binding protein-3 in healthy premenopausal women. Cancer Epidemiology Biomarkers and Prevention $200110377-384$.

19 Rosen CJ, Kurland ES, Vereault D, Adler RA, Rackoff PJ, Craig WY, Witte S, Rogers J \& Bilezikian JP. Association between serum insulin growth factor-I (IGF-I) and a simple sequence repeat in IGF-I gene: implications for genetic studies of bone mineral density. Journal of Clinical Endocrinology and Metabolism $1998 \mathbf{8 3}$ 2286-2290.

20 Missmer SA, Haiman CA, Hunter DJ, Willett WC, Colditz GA, Speizer FE, Pollak MN \& Hankinson SE. A sequence repeat in the insulin-like growth factor- 1 gene and risk of breast cancer. International Journal of Cancer 2002100 332-336.

21 Rietveld I, Janssen JA, Hofman A, Pols HA, Van Duijn CM \& Lamberts SW. A polymorphism in the IGF-I gene influences the age-related decline in circulating total IGF-I levels. European Journal of Endocrinology $2003 \mathbf{1 4 8} 171-175$.

22 Fletcher O, Gibson L, Johnson N, Altmann DR, Holly JM, Ashworth A, Peto J \& Silva IS. Polymorphisms and circulating levels in the insulin-like growth factor system and risk of breast cancer: a systematic review. Cancer Epidemiology Biomarkers $\mathcal{E}$ Prevention $2005142-19$.

23 Hovind P, Tarnow L, Rossing P, Jensen BR, Graae M, Torp I, Binder C \& Parving HH. Predictors for the development of microalbuminuria and macroalbuminuria in patients with type 1 diabetes: inception cohort study. British Medical Journal 2004 3281105.

24 Hovind P, Tarnow L, Rossing K, Rossing P, Eising S, Larsen N, Binder C \& Parving HH. Decreasing incidence of severe diabetic microangiopathy in type 1 diabetes. Diabetes Care 200326 1258-1264.
25 Faber OK. B-cell function and blood glucose control in insulin dependent diabetics within the first month of insulin treatment. Diabetologia 197713 263-268.

26 Lizana J \& Hellsing K. Polymer enhancement of automated immunological nephelometric analysis, as illustrated by determination of urinary albumin. Clinical Chemistry 197420 415-420.

27 Miles DW, Mogensen CE \& Gundersen HJ. Radioimmunoassay for urinary albumin using a single antibody. Scandinavian Journal of Clinical and Laboratory Investigation 1970 26 5-11.

28 Feldt-Rasmussen B, Dinesen B \& Deckert M. Enzyme immunoassay: an improved determination of urinary albumin in diabetics with incipient nephropathy. Scandinavian Journal of Clinical and Laboratory Investigation 198545 539-544.

29 Rossing P, Hommel E, Smidt UM \& Parving HH. Impact of arterial blood pressure and albuminuria on the progression of diabetic nephropathy in IDDM patients. Diabetes 199342 715-719.

30 Parving HH, Lehnert H, Brochner-Mortensen J, Gomis R, Andersen S \& Arner P. The effect of irbesartan on the development of diabetic nephropathy in patients with type 2 diabetes. New England Journal of Medicine 2001345 870-878.

31 Juul A, Holm K, Kastrup KW, Pedersen SA, Michaelsen KF, Scheike T, Rasmussen S, Muller J \& Skakkebaek NE. Free insulin-like growth factor I serum levels in 1430 healthy children and adults, and its diagnostic value in patients suspected of growth hormone deficiency. Journal of Clinical Endocrinology and Metabolism 199782 2497-2502.

32 Rietveld I, Janssen JA, van Rossum EF, HouwingDuistermaat JJ, Rivadeneira F, Hofman A, Pols HA, Van Duijn CM \& Lamberts SW. A polymorphic CA repeat in the IGF-I gene is associated with gender-specific differences in body height, but has no effect on the secular trend in body height. Clinical Endocrinology 200461 195-203.

33 Kostek MC, Delmonico MJ, Reichel JB, Roth SM, Douglass L, Ferrell RE \& Hurley BF. Muscle strength response to strength training is influenced by insulin-like growth factor 1 genotype in older adults. Journal of Applied Physiology 200598 2147-2154.

34 Hambrecht R, Schulze PC, Gielen S, Linke A, Mobius-Winkler S, Erbs S, Kratzsch J, Schubert A, Adams V \& Schuler G. Effects of exercise training on insulin-like growth factor-I expression in the skeletal muscle of non-cachectic patients with chronic heart failure. European. Journal of Cardiovascular Prevention \& Rehabilitation 200512 401-406.

35 Chestnut RE \& Quarmby V. Evaluation of total IGF-I assay methods using samples from type I and type II diabetic patients. Journal of Immunological Methods 2002259 11-24.

36 Martin RM, Holly JM, Smith GD, Ness AR, Emmett P, Rogers I \& Gunnell D. Could associations between breastfeeding and insulinlike growth factors underlie associations of breastfeeding with adult chronic disease? the avon longitudinal study of parents and children Clinical Endocrinology 200562 728-737.

37 Sowers JR. Insulin and insulin-like growth factor in normal and pathological cardiovascular physiology. Hypertension 199729 691-699.

38 Delafontaine P, Song YH \& Li Y. Expression, regulation, and function of IGF-1, IGF-1R, and IGF-1 binding proteins in blood vessels. Arteriosclerosis, Thrombosis, and Vascular Biology 200424 435-444.

39 Walsh MF, Barazi M, Pete G, Muniyappa R, Dunbar JC \& Sowers JR. Insulin-like growth factor I diminishes in vivo and in vitro vascular contractility: role of vascular nitric oxide. Endocrinology 1996137 1798-1803.

Received 19 June 2006

Accepted 5 October 2006 